Zoologica Poloniae (2011) 56/1-4: 5-10

DOI: $10.2478 / \mathrm{v} 10049-011-0003-9$

\title{
SIGARA DORSALIS (LEACH, 1817) (HETEROPTERA: CORIXIDAE) - A NEW SPECIES IN POLAND AND CHANGES IN ITS EASTERN RANGE EXTENSION
}

\author{
Alicja KurzĄTKOWsKA ${ }^{1}$ and Andrzej ZaWAL ${ }^{2}$
}

\footnotetext{
1 Department of Ecology and Environmental Protection, Faculty of Biology, University of Warmia and Mazury in Olsztyn, Plac Łódzki 3, 10-727 Olsztyn, Poland,e-mail: akurz@uwm.edu.pl

2 Department of Invertebrate Zoology and Limnology, University of Szczecin, Wąska 13, 71-415 Szczecin, Poland, e-mail: zawal@univ.szczecin.pl
}

\begin{abstract}
Sigara dorsalis is a new species of the family Corixidae in Poland. It has been identified based on a single male individual in the valley of the Krapiel River (West Pomerania). Recently reported also from the Mecklenburg region, Sigara dorsalis seems to show a tendency to spread towards the east.
\end{abstract}

Key words: Sigara dorsalis (Leach, 1817), Heteroptera, Corixidae, geographical range, new species in Poland.

To date, 34 Corixidae species have been identified in Poland (MielewczyK 1990), and until recently, the list of taxa was believed to be complete. Meanwhile, an in-depth research study in the valley of the Krapiel River (West Pomerania) revealed a new species in the Polish fauna, Sigara dorsalis. Aquatic Heteroptera inhabiting water bodies in West Pomerania remain poorly researched. Among a limited amount of new research, one study investigating water bodies in the "Lake Szare" Reserve has been published (KurZąTKowsKa and ZawAL 2007). Historical data is also scant, but it suggests the absence of the discussed species in the area in the past (STICHEL 1934-1935, KARL 1935, WróBlewSKi 1952).

$S$. dorsalis is a West European species encountered in the coastal Atlantic belt covering western Scandinavia (Norway, south Sweden - JANSSON 1986, Coulianos et al. 2008), Mecklenburg (Vorpommern, Germany - Martschei and Engelmann, 2001), the British Isles, Belgium, France (Southwood and Leston 
1959, Savage 1971, Jansson 1986, Savege and Feakes 1991, Tully et al. 1991), the Alpine region (Switzerland, Austria - Dethier 2001, Rabitsch 2004), the western Mediterranean coast (north-eastern Spain, north Italy) and Greece (NIESER 1978, Murillo 1985, Boix et al. 2001, Valladares et al. 2002, Karaouzas and Gritzalis 2006, Martinoy et al. 2006, Goula et al. 2010). The identification of $S$. dorsalis in the area of Szczecin should not come as a surprise since the species has been found to inhabit the neighboring region of Mecklenburg. The discovery of $S$. dorsalis in Mecklenburg in the 1980s (Martschei and EngelmanN 2001), and the recent identification of the species in West Pomerania may suggest that $S$. dorsalis has a tendency to spread in the eastern direction (Figure 1). It remains unclear whether recent reports of $S$. dorsalis from Spain are due to the range expansion of this species or a lack of previous surveys in the area.

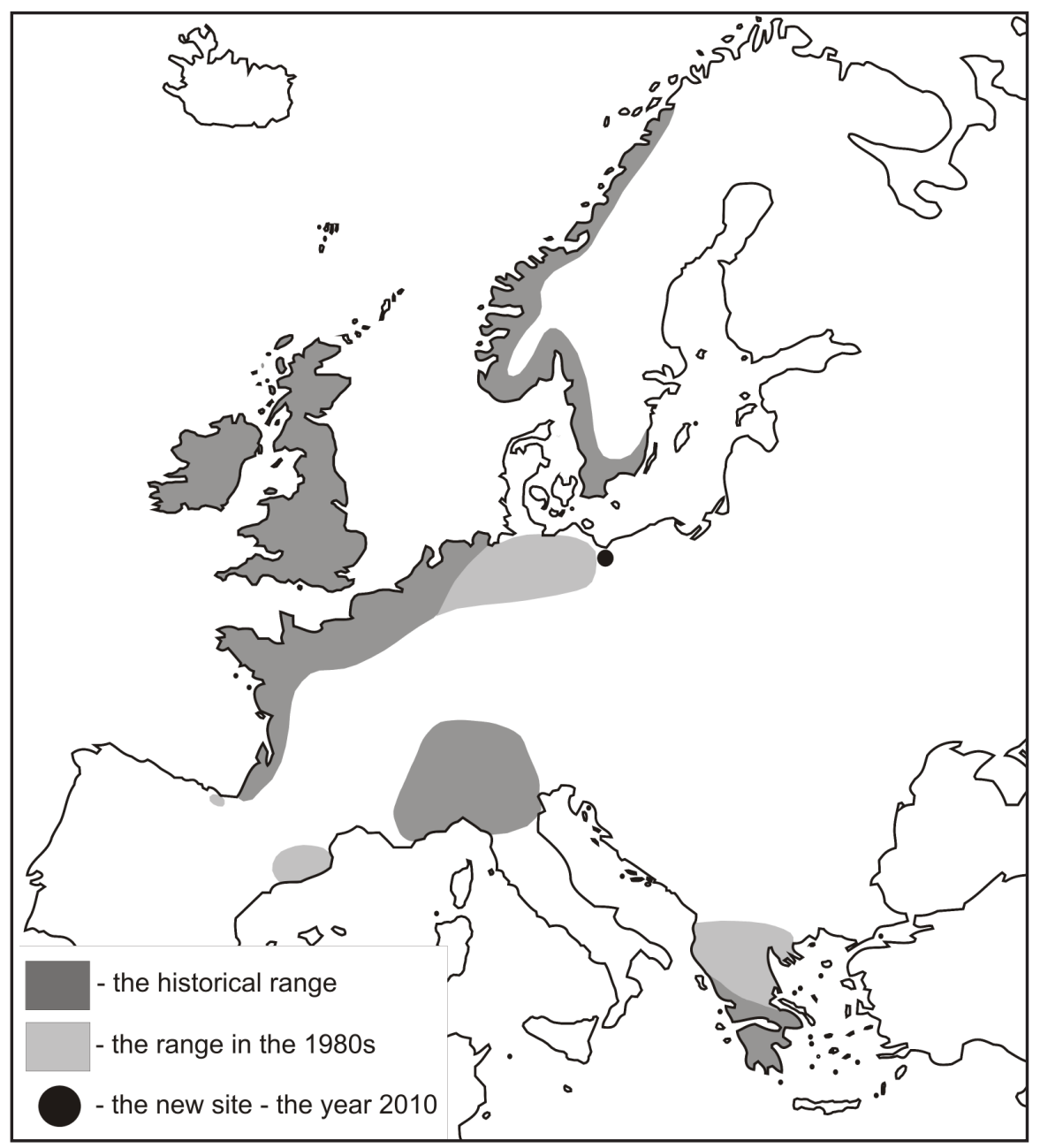

Figure 1. The geographical range of Sigara dorsalis 
S. dorsalis is characterized by a broad habitat range. It inhabits both standing and running waters with a relatively slow flow (rivers, channels, ditches). The species shows a preference for waters with different $\mathrm{pH}$ and salinity levels (Hammond 2007). It occupies water bodies with a sandy or gravel bottom and a low organic matter content. S. dorsalis is found in the shallow littoral zone of mesotrophic lakes, and ponds and watercourses with a sandy bottom (MACAN 1939, 1954a, b, 1965, Southwood and Leston 1959, Tully et al. 1991).

$S$. dorsalis shows many similarities to $S$. striata, and it has been long considered to be synonymous with the latter species. A distinction between the two species can be made based solely on observations of male individuals, taking into account the appearance of the palae (fore tarsus) and both parameres (JANSSON 1986, Savage 1989, 1990a, Savage and Parkin 1998, Angus and Moody 2008).

The British Isles are situated in the center of the geographic range of S. dorsalis which is a common and an abundant species there (JANSSON 1986). $S$. dorsalis occurs sympatrically with $S$. striata in south-east England which is the western range limit of the latter species. Numerous specimens collected in that region testify to the presence of interspecific hybrids (SAVAGE 1989). The „pure" populations of $S$. dorsalis are marked by high variability, in particular with regard to the morphological characteristics of the right paramere (an intermediary character between $S$. dorsalis and $S$. striata). A cross between members of geographically remote populations of S. striata (Finland) and S. dorsalis (Scotland) produced hybrids whose right parameres were practically indistinguishable from those of the „pure” $S$. dorsalis population. It is, therefore, believed that the morphological variability of $S$. dorsalis reflects the original genotype of its wild population, and it also points to a closeness between the investigated species and S. striata (Savage and Feakes 1991).

\section{MATERIAL AND METHODS}

Samples were collected along the entire length of the Krapiel River valley (West Pomerania), from April to September 2010. Fourteen sampling sites and several sub-sites were established, covering the river, heads of the river (helocrene and limnocrene springs), streams, oxbow lakes and overflow areas. Samples were collected at monthly intervals, using a scoop net with a triangular frame $(20 \mathrm{x}$ $20 \times 20 \mathrm{~cm}$ ). Depending on habitat diversity, samples were collected in triplicate from five to nine aquatic environment types at each site. A single sample comprised 10 scoops over a water surface area of approximately $1 \mathrm{~m}^{2}$.

In a total of over 650 water samples, water bugs were represented by approximately 8500 individuals, including almost 1500 members of 17 Corixidae species.

\section{Sampling site where Sigara dorsalis was found}

The sampling site was situated in the Nowogard Plain (KONDRACKI 2000), in the Old Krapiel River valley (N53024'16,54"; E15 $\left.11^{\prime} 48,41^{\prime \prime}\right)$. Along the studied section, the river divides into two channels - the old (Stara Krąpiel) channel 
with minimal flow and dense vegetation, and the new (Krapiel) channel dug before World War II, the main watercourse of the river. The river bed was set on lowmoor peat overgrown with plants characteristic of the local flora. Valley shores featured an alder carr forest as well as artificially planted spruce trees which were decimated by long-term flooding.

The sub-site where Sigara dorsalis was sampled is located on the left side of the old Krapiel River valley, around $50 \mathrm{~m}$ from its watercourse, in a shallow drainage ditch which dries up in the summer (depth $0.2 \mathrm{~m}$, width $1.5 \mathrm{~m}$ ). The banks of the ditch were overgrown with Glyceria maxima, and its peat bottom was covered by mud. The water in the ditch was slightly acidic ( $\mathrm{pH} 5.5)$.

In the study area, Sigara dorsalis was identified based on a single male individual (sampling date: 7 May, 2010). The analyzed individual exhibited morphological features typical of the species: right paramere with a subapical tooth on the caudal side and a strong excision of the dorsal margin towards the base, the basal couple of palar pegs in the outer row, in line with the others (Figure 2). The fact that only a single individual was caught may be explained by low species abundance as well as the impossibility to identify females and particularly larvae of Sigara dorsalis.
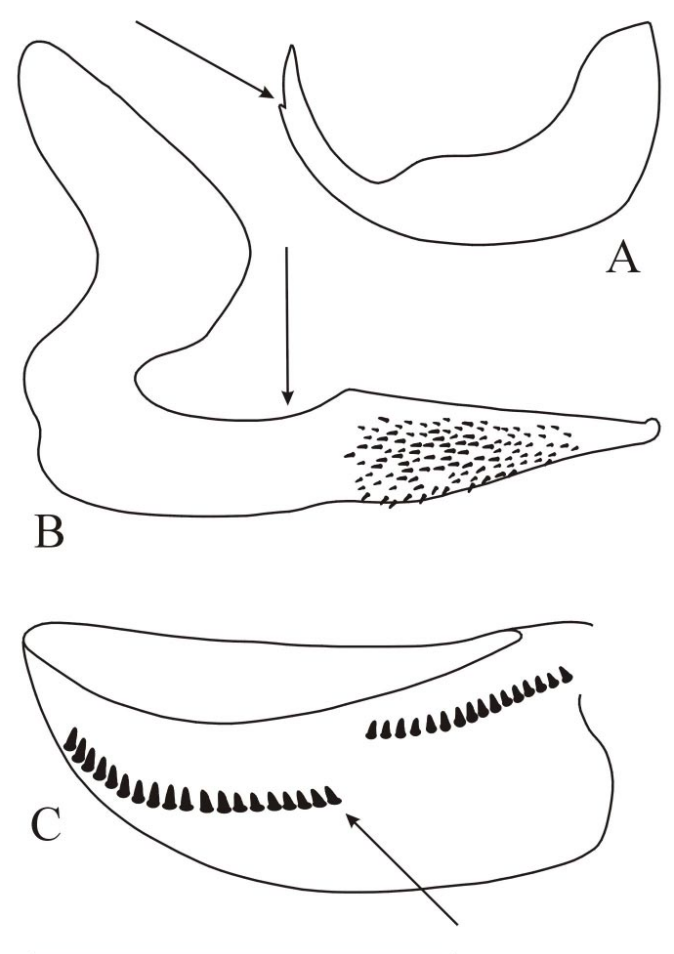

Figure 2. Parameres and pala of Sigara dorsalis; A - right paramere, B - left paramere, C - palar pegs (scale line $0.5 \mathrm{~mm}$ ) 


\section{Acknowledgements}

Financial support was provided by the Ministry of Science and Higher Education. This study has been carried out as part of research grant No. N305 222537 covering 2009-2012.

\section{SIGARA DORSALIS (LEACH, 1817) (HETEROPTERA: CORIXIDAE) NOWY GATUNEK DLA POLSKI I ZMIANY WSCHODNIEJ CZĘŚCI JEGO ZASIĘGU}

\section{STRESZCZENIE}

Sigara dorsalis jest nowym dla fauny Polski gatunkiem wioślaka, odnotowanym w dolinie rzeki Krąpiel (Pomorze Zachodnie). Gatunek został stwierdzony na podstawie pojedynczego samca. Stosunkowo niedawne wykazanie Sigara dorsalis z obszarów Maklemburgii, a teraz także z Pomorza Zachodniego, może wskazywać na tendencję gatunku do rozszerzania swego zasięgu w kierunku wschodnim.

\section{REFERENCES}

Angus R. and Moody G. 2008: Morphological intergradation between Sigara dorsalis \& S. striata. In: An informal email newsletter circulated periodically to those interested in Heteroptera. Het News, 2nd series, 11: 7-8.

Boix D., Sala J. and Moreno-Amich R. 2001: The faunal composition of Espolla Pond (NE Iberian Peninsula): the neglected biodiversity of temporary waters wetlands. The Society of Wetland Scientists 21(4): 577-592.

Coulianos C.C., ØKLand J. and ØKLand K.A. 2008: Norwegian water bugs. Distribution and ecology (Hemiptera-Heteroptera: Gerromorpha and Nepomorpha). Norw. J. Ent. 55: 179-222.

Dethier M. 2001: Présence de Sigara dorsalis (Leach, 1817) en Suisse (Heteroptera Corixidae). Bull. Romand d'Ent. 19: 17-21.

Goula M., Ribes J. and Serra A. 2010: Checklist of Heteroptera of Catalonia (Insecta, Hemiptera, Heteroptera). Centre de Recursos de Biodiversitat Animal, Facultat de Biologia, Universitat de Barcelona. Version 1, 38 p.

Hammond M. 2007: The water bugs of Cleveland with a note on northwards expansions in range in: Cleveland Naturalists' field Club, vol. 9 Part 1, 34 p.

JAnsson A. 1986: The Corixidae (Heteroptera) of Europe and some adjacent regions. Acta ent. fenn. 47: 1-94.

Karaouzas I. and Gritzalis K. C. 2006: Local and regional factors determining aquatic and semi-aquatic bug (Heteroptera) assemblages in rivers and streams of Greece. Hydrobiol. 573(1): 199-212.

KARL O. 1935: Ein Beitrag zur Hemipterenfauna Ostpommerns. Wanzen, Zikaden und Btattflöche. Dohrniana, Stettin, 14: 122-141.

Kondracki J. 2000: Geografia regionalna Polski. PWN, Warszawa, 463 p.

Kurzatikowska A. and Zawal A. 2007: Pluskwiaki wodne (Heteroptera) rezerwatu „Jezioro Szare” i jego otuliny. Parki nar. Rez. Przyr., 26(4): 93-104. (In Polish with summary in English)

MaCAn T.T. 1939: A key to the British species of Corixidae (Hemiptera - Heteroptera) with notes on their distribution. Scient. Publ. Freshwat. biol. Ass. 1: 27 p.

Macan T.T. 1954a: The Corixidae (Hemipt.) of some Danish lakes. Hydrobiologia, 6: 44-69. 
Macan T.T. 1954b: Corixa dorsalis Leach (Hem. Corixidae) raised from synonymy in the British list. Entomologist's mon. Mag., 90: 216.

MACAN T.T. 1965: A revised key to the British water bugs (Hemiptera - Heteroptera) with notes on their ecology. $2^{\text {nd }}$ edition. Scient. Publ. Freshwat. biol. Ass., 16: 1-78.

Martinoy M., Boix D., Sala J., Gascón S., Gifre J., Argerich A., de la Barrera R., Brucet S., Badosa A., López-Flores R., Méndez M., Utgé J.M. and Quintana X.D. 2006: Crustacean and aquatic insect assemblages in the Mediterranean coastal ecosystems of Empordá wetlands (NE Iberian peninsula) Limnetica, 25 (3): $665-682$.

Martschei T. and Engelmann H.D. 2001: Vorläufiges Verzeichnis der bisher bakannten Wanzenarten Mecklenburg-Vorpommerns. Heteropteren, 10: 19-29.

Mielewczyk S. 1990: Heteroptera - pluskwiaki różnoskrzydłe. Heteroptera aquatica et semiaquatica - pluskwiaki wodne: Nepomorpha i Gerromorpha. In: Razowski J. (ed.), Wykaz zwierząt Polski. Inst. Syst. i Ewol. Zw. PAN, Ossolineum, Wrocław-Warszawa-Kraków, 1: 71-73. (In Polish)

Murillo J. 1985: Algunes captures d'Heteropters aquatics efectuades a Catalunya i altres localitats de la Resta de la Peninsula Iberica. Butll. Inst. Cat. Hist. Nat., 52 (Sec. Zool., 6): 139-147.

Nieser N. 1978: Heteroptera. In: Illies J. (ed.), Limnofauna Europaea. A checklist of the animals inhabiting European inland waters, with accounts of their distribution and ecology. Stuttgart-New York-Amsterdam, 280-285

Rabitsch W. 2004: Annotations to a check-list of the Heteroptera of Austria. Ann. Naturhist. Mus. Wien, 105B, 453-492.

SAvage A.A. 1971: The Corixidae of some inland saline lakes in Cheshire, Entomologist, 104: $331-344$.

Savage A.A. 1989: Adults of the British aquatic Hemiptera Heteroptera: a key with ecological notes. Scient. Publ. Freshwat. biol. Ass. 50: 173 p.

SAVAge A.A. 1990a: A key to the adults of British lesser water boatmen (Corixidae). Field Studies, 7: 485-515.

SAVAGE A.A. and FEAKES K. 1991: Morphological variation with interspecific implication in a population of Sigara dorsalis (Leach) (Hemiptera Heteroptera: Corixidae). Freshwater Forum, 1: 73-77, http://aquacomm.fcla.edu /4521/1/AASavage.pdf

SAVAGe A.A. and Parkin E.J., 1998: The diagnostic morphological features of British Sigara striata, $S$. dorsalis \& intermediate specimens (Corixidae), with a key for identification of adult males. Freshwater Forum, 10: 35-48.

Southwood T.R.E. and Leston D. 1959: Land and Water Bugs of the British Isles. Warne-London, $436 \mathrm{p}$.

Stichel W. 1934-1935: Illustrierte Bestimmungstabellen der Deutschen Wanzen. BerlinLeipzig, 10-11.

Tully O., McCarthy T.K. and O'Donnell D. 1991: The ecology of the Corixidae (Hemiptera: Heteroptera) in the Corrib catchment, Ireland, Hydrobiologia, 210: 161-169.

Valladares L.F., Vega F.J., Mazé R.A., Régil J.A. and García-Criado F. 2002: Biodiversidad de los macroinvertebrados acuáticos del Parque Natural de Valderejo (Álava): implicaciones en conservación Boln. Asoc. esp. Ent., 26(3-4): 37-55.

Wróblewski A. 1952: Pluskwiaki różnoskrzydłe (Hemiptera-Heteroptera) wód Wyspy Wolina (Pomorze Zachodnie). Pr. Kom. Biol., Pozn., TPN Poznań, 13: 1-21. (In Polish) 